OPEN ACCESS

Edited by: Juan Francisco Jimenez Bremont, Instituto Potosino de Investigación Científica y Tecnológica, Mexico

Reviewed by: María De La Luz Guerrero González, Universidad Autónoma de San Luis Potosí, Mexico Rosalia Cristina Paz, CIGEOBIO (CONICET/FCEFN, UNSJ), Argentina

*Correspondence: Arthur G. Fett-Neto fettneto@cbiot.ufrgs.br

${ }^{\dagger}$ These authors have contributed equally to this work.

Specialty section: This article was submitted to Plant Physiology, a section of the journal Frontiers in Plant Science

Received: 08 December 2015 Accepted: 30 May 2016 Published: 16 June 2016

Citation: de Lima JC, de Costa F, Füller TN, Rodrigues-Corrêa KCdS, Kerber MR, Lima MS, Fett JP and Fett-Neto AG

(2016) Reference Genes for qPCR Analysis in Resin-Tapped Adult Slash

Pine As a Tool to Address the Molecular Basis of Commercial Resinosis. Front. Plant Sci. 7:849. do: $10.3389 / f p / s .2016 .00849$

\section{Reference Genes for qPCR Analysis in Resin-Tapped Adult Slash Pine As a Tool to Address the Molecular Basis of Commercial Resinosis}

\author{
Júlio C. de Lima ${ }^{1 \dagger}$, Fernanda de Costa ${ }^{1 \dagger}$, Thanise N. Füller ${ }^{1}$, \\ Kelly C. da Silva Rodrigues-Corrêa ${ }^{2}$, Magnus R. Kerber ${ }^{1}$, Mariano S. Lima ${ }^{1}$, \\ Janette P. Fett ${ }^{1}$ and Arthur G. Fett-Neto ${ }^{1 *}$
}

\footnotetext{
${ }^{1}$ Plant Physiology Laboratory, Center for Biotechnology and Department of Botany, Federal University of Rio Grande do Sul, Porto Alegre, Brazil, ${ }^{2}$ Biological Sciences Department, Regional Integrated University of Alto Uruguai and Missões (URI-FW), Frederico Westphalen, Brazil
}

Pine oleoresin is a major source of terpenes, consisting of turpentine (mono- and sesquiterpenes) and rosin (diterpenes) fractions. Higher oleoresin yields are of economic interest, since oleoresin derivatives make up a valuable source of materials for chemical industries. Oleoresin can be extracted from living trees, often by the bark streak method, in which bark removal is done periodically, followed by application of stimulant paste containing sulfuric acid and other chemicals on the freshly wounded exposed surface. To better understand the molecular basis of chemically-stimulated and wound induced oleoresin production, we evaluated the stability of 11 putative reference genes for the purpose of normalization in studying Pinus elliottii gene expression during oleoresinosis. Samples for RNA extraction were collected from field-grown adult trees under tapping operations using stimulant pastes with different compositions and at various time points after paste application. Statistical methods established by geNorm, NormFinder, and BestKeeper softwares were consistent in pointing as adequate reference genes HISTO3 and $U B I$. To confirm expression stability of the candidate reference genes, expression profiles of putative $P$. elliottii orthologs of resin biosynthesis-related genes encoding Pinus contorta $\beta$-pinene synthase [PCTPS-(-) $\beta$-pin1], P. contorta levopimaradiene/abietadiene synthase (PCLAS1), Pinus taeda $\alpha$-pinene synthase [PtTPS- $(+) \alpha p i n]$, and $P$. taeda $\alpha$-farnesene synthase (PtaFS) were examined following stimulant paste application. Increased oleoresin yields observed in stimulated treatments using phytohormone-based pastes were consistent with higher expression of pinene synthases. Overall, the expression of all genes examined matched the expected profiles of oleoresin-related transcript changes reported for previously examined conifers.

Keywords: resin, Pinus, gene expression, normalizer genes, terpene synthase 


\section{INTRODUCTION}

Pine oleoresin is a major source of terpenes, consisting of turpentine (mono- and sesquiterpenes) and rosin (diterpenes) fractions. Oleoresin represents a key element of defense in conifers and its production can be affected by biotic and abiotic factors, which include mechanical injury, pathogen attack, water availability, seasonality, and chemical stimulating treatments (Rodrigues-Corrêa and Fett-Neto, 2012). Higher oleoresin yields are economically desirable, since oleoresin derivatives make up a valuable source of materials for chemical industries (RodriguesCorrêa et al., 2012). Currently, oleoresin is extracted for commercial purposes from living trees, often by the bark streak method, in which bark removal is done periodically, followed by application of chemical stimulant paste containing sulfuric acid and other chemicals on the freshly wounded exposed surface (Rodrigues-Corrêa et al., 2013). Chemical stimulant pastes may contain phytohormones or their precursors (e.g., ethylene, auxin, salicylic acid), metal ions (enzyme activators or co-factors, such as potassium and iron), or reactive oxygen species generators (e.g., paraquat), all of which increase resin production and/or facilitate its flow by activating defense responses (RodriguesCorrêa and Fett-Neto, 2012).

Terpenes of conifers are mostly biosynthesized by secretory tissue in the inner surface of resin ducts present in conifer bark and xylem, in the cambium zone, and associated vascular tissues (Back, 2002). Resin accumulates within the ducts, exerting positive pressure on its walls, thereby being exuded upon wounding (Trapp and Croteau, 2001). Terpenes are derived from isopentenyl pyrophosphate (IPP), produced either through the mevalonate pathway in the cytosol-endoplasmic reticulum or by deoxi-xylulose-5-phosphate pathway in the plastids (Phillips and Croteau, 1999).

The pathway of terpene biosynthesis may be divided in various stages. First, IPP is synthesized and isomerized to dimethyl allyl diphosphate (DMPP). Then, prenyltransferases catalyze the condensation of these two $\mathrm{C} 5$-units to geranyl diphosphate (GPP), forming monoterpenes $\left(\mathrm{C}_{10}\right)$, and the subsequent $1^{\prime}$ 4 head-to-tail additions of isopentenyl diphosphate generate farnesyl (FPP) and geranylgeranyl (GGPP) diphosphate, which fuse to originate sesquiterpenes $\left(C_{15}\right)$ and diterpenes $\left(C_{20}\right)$, respectively. Next, the prenyl diphosphates undergo a range of cyclizations driven by terpene synthases (TPS) and other modifying reactions to produce the immense diversity of different terpenoid metabolites (Rodrigues-Corrêa et al., 2013).

Although chemical stimulant pastes have been intensely studied in Pinus elliottii Engelm var. elliottii (slash pine) aiming at higher yields of oleoresin (Rodrigues et al., 2008, 2011; Rodrigues and Fett-Neto, 2009; Rodrigues-Corrêa and Fett-Neto, 2013), knowledge of genes and their regulatory pattern for terpene biosynthesis in commercial forests are still unknown. Acquiring this information would be a crucial aspect to understand the biochemical and physiological basis of oleoresin production. Hence, the aim of this study was to evaluate the stability of 11 putative reference genes for the purpose of normalization in studying $P$. elliottii gene expression during oleoresinosis under field conditions, undergoing tapping operation with different stimulant pastes and at different time points after paste application. Statistical methods established by geNorm (Vandesompele et al., 2002), NormFinder (Andersen et al., 2004), and BestKeeper (Pfaffl et al., 2004) were comparatively used to analyze the data. In addition, to confirm stability of the candidate reference genes, expression profiles of putative $P$. elliottii orthologs of conifer genes encoding several terpene synthases involved in biosynthesis of different resin components were monitored following stimulant paste application.

\section{MATERIALS AND METHODS}

\section{Plant Material and Resin Tapping Process}

Approximately 16 years-old slash pine ( $P$. elliottii Engelm. var. elliottii) trees with a diameter at breast height ranging from 65 to $90 \mathrm{~cm}$, grown at Irani Celulose forest installations, Balneário Pinhal, RS, Brazil $\left(30^{\circ} 14^{\prime} \mathrm{S}\right.$ and $\left.50^{\circ} 14^{\prime} \mathrm{W}\right)$, were used in the experiments. Resin tapping was performed according to a protocol previously established (Rodrigues et al., 2011) based on Pio and Valente (1998), using the "bark streak" system (Stubbs et al., 1984). Each stimulant paste contained $20 \%$ of sulfuric acid in aqueous solution and rice husk powder as an inert substrate to optimize paste consistency. Single modifications in the composition of the resin stimulant paste were done by including $1.0 \mathrm{mM}$ of the synthetic auxin 1-naphthaleneacetic acid (Treatment name: NAA), $500 \mathrm{mM}$ potassium sulfate (Treatment name: POTASSIUM) or 3\% of 2-chloroethylphosphonic acid (Treatment name: CEPA) (v/v of active ingredient, an ethylene releasing agent). A negative control without paste application (bark streak only) was also included. The treatments and rationale for application are listed in Table $\mathbf{1}$.

Each treatment consisted of five trees randomly selected, each located in the inner portion of the forest, excluding the trees in forest borders. The trees used in this study had been previously tapped for resin production biweekly for one year with the respective stimulant paste. For this experiment, the process of tapping and application of stimulant paste directly on the fresh wounds occurred only once. Immediately after paste application and after 5, 8, and 15 days, a novel mini bark streak was made right above the previous one, phloem tissues were removed using a wood chisel and the cambium was exposed (Figure 1). Vascular cambium was scrapped and the removed tissue was immediately frozen in liquid nitrogen and kept at $-80^{\circ} \mathrm{C}$ until RNA extraction. Tissue had to be harvested slightly above the wound streak due to poor quality of RNA obtained in the wound line itself. The mini bark streak approach was also chosen because it is known that stimulant chemicals in paste can move upward and sideways in the tree, affecting surrounding tissues (Brown and Nix, 1975; Rodrigues-Corrêa and Fett-Neto, 2012).

Biomass of resin yielded by each treatment was estimated as an average for one bark streak based on the winter season production of 80 individual trees of the same stand.

\section{Isolation of RNA and First Strand cDNA Synthesis}

Total RNA was isolated from vascular cambium of slash pine plants using Concert plant RNA reagent (Life Technologies), 
TABLE 1 | Oleoresin stimulant paste adjuvant treatments tested under field conditions on bark wounds of $P$. elliottii.

\begin{tabular}{|c|c|c|}
\hline Treatment & Adjuvant & Mode of action \\
\hline POTASSIUM & Potassium sulfate & $\begin{array}{l}\text { Potassium is a cofactor of } \\
\text { conifer terpenoid synthases } \\
\text { (Savage et al., 1994; Trapp } \\
\text { and Croteau, 2001; } \\
\text { Rodrigues et al., 2011) }\end{array}$ \\
\hline NAA & Naphthaleneacetic acid & $\begin{array}{l}\text { Promotes ethylene } \\
\text { biosynthesis (increases ACC } \\
\text { synthase gene transcription) } \\
\text { and may induce resin duct } \\
\text { formation, as a result of } \\
\text { cambial activity stimulation } \\
\text { (Chae and Kieber, 2005; } \\
\text { Song et al., 2005; } \\
\text { Rodrigues and Fett-Neto, } \\
\text { 2009) }\end{array}$ \\
\hline CEPA & 2-Chloroethylphosphonic acid & $\begin{array}{l}\text { Precursor of ethylene, } \\
\text { signaling molecule involved } \\
\text { in stress-induced } \\
\text { responses, increases } \\
\text { biosynthesis of mono- and } \\
\text { diterpenes (reviewed in } \\
\text { Rodrigues-Corrêa et al., } \\
\text { 2013) }\end{array}$ \\
\hline
\end{tabular}

following manufacturer indications. Total RNA (500 ng) was treated with $1 \mathrm{U}$ DNAse I and DNAse I reaction buffer (Life Technologies) before cDNA synthesis. Total RNA concentration was determined using an UV spectrophotometer (Nanodrop, Thermo Scientific) and nucleic acid quality was checked with 2100 Bioanalyzer instrument (Agilent). For the amplification of the candidate reference genes, all treated RNA was reverse transcribed using oligo-dT primers and M-MLV reverse transcriptase (Life Technologies) in a final volume of $20 \mu$ l. The final cDNA products were diluted 50-fold in RNAse-free distilled water prior to use in qPCR.

\section{PCR Primer Design}

Eleven genes were selected as candidate internal controls and are described in Table 2. Genes were previously reported as reference genes in embryogenesis studies with other conifer species such as P. taeda, P. pinaster, and Picea abies (Gonçalves et al., 2005; de Vega-Bartol et al., 2013). Primers for ACT, $A T U B, C Y P$ and $e E F$ genes were designed with Primer3 v 0.40 (Applied Biosystems, Foster City, CA, USA) using the default parameters of the software. Primers for all other candidate genes were employed as reported in conifer embryogenesis studies (Gonçalves et al., 2005; de Vega-Bartol et al., 2013). All primer pairs were checked for their probability to form dimers and secondary structures. Expression profiles of putative $P$. elliottii orthologs of resin biosynthesis-related genes were also examined following different stimulant paste application. To that end, the best pair of reference genes selected in this study was used as normalizer and the data were analyzed by the different softwares. Primers for amplifying transcripts of the various terpene synthase genes are listed in Table S1.

\section{Amplification and Sequencing of the Reference Genes}

All genes were amplified from the pooled cDNA and reactions were carried out in total volumes of $50 \mu \mathrm{l}$, containing template cDNA (1:50 dilution in water), 10 X PCR Buffer, $10 \mathrm{mM}$ dNTPs, $50 \mathrm{mM} \mathrm{MgCl}, 10 \mu \mathrm{M}$ each primer (forward and reverse) and 5 U/ $\mu$ l Platinum Taq polymerase. The cycling conditions for the amplification of PCR products involved an initial denaturation of $95^{\circ} \mathrm{C} / 5 \mathrm{~min}$, followed by 40 cycles of $95^{\circ} \mathrm{C} / 30 \mathrm{~s}$, primer-specific annealing temperature $/ 30 \mathrm{~s}$ and $72^{\circ} \mathrm{C} / 30 \mathrm{~s}$.

Specificity of each primer pair was verified by sequencing amplicons in an ABI 3100 automatic DNA sequencer (Life Technologies). Proper sizes of amplification products were further confirmed by gel electrophoresis on $1 \%$ agarose gel and visualization after staining with ethidium bromide.

\section{qPCR}

The synthesized cDNA was diluted 1:50 with RNAse-free distilled water, and $10 \mu \mathrm{l}$ of the diluted cDNA was used as a template for quantitative real-time PCR analysis. PCR reactions were carried out in a technical quadruplicate for each sample and performed in a total volume of $20 \mu \mathrm{l}$ as described previously (de Almeida et al., 2010). All analyses were performed using three biological replicates for each time point and individual treatment. Reactions were performed in fast optical 48-well reaction plates $0.1 \mathrm{ml}$ (MicroAmp ${ }^{\mathrm{TM}}$-Applied Biosystems) using a StepOne ${ }^{\mathrm{TM}}$ Real-Time PCR System (Applied Biosystems) according to the manufacturer instructions. PCR amplifications included an initial denaturation step of $5 \mathrm{~min}$ at $95^{\circ} \mathrm{C}$, followed by 40 cycles of $15 \mathrm{~s}$ at $95^{\circ} \mathrm{C}, 10 \mathrm{~s}$ at $60^{\circ} \mathrm{C}$, and $15 \mathrm{~s}$ at $72^{\circ} \mathrm{C}$, after which samples were held for $2 \mathrm{~min}$ at $40^{\circ} \mathrm{C}$ for annealing and then heated from 55 to $99^{\circ} \mathrm{C}$ with a ramp of $0.1^{\circ} \mathrm{C} / \mathrm{s}$ to produce the denaturing curve (or melting curve) of the amplified products. Melting curves were used to validate product specificity. Obtained data were analyzed by the comparative $\mathrm{C}_{\mathrm{q}}$ (quantitative cycle method) (Livak and Schmittgen, 2001). The PCR efficiency from the exponential phase (Eff) was calculated for each individual amplification plot using the LinReg software (Ramakers et al., 2003). In each plate, the average of PCR efficiency for each amplicon was determined and used in further calculations.

\section{Selection of Potential Reference Genes}

Three softwares, geNorm (Vandesompele et al., 2002), NormFinder (Andersen et al., 2004), and BestKeeper (Pfaffl et al., 2004), were used to select the most stably expressed reference genes during slash pine oleoresinosis. Expression stability of the candidate reference genes was first ranked using geNorm and the output was compared to the results of NormFinder and BestKeeper.

The geNorm algorithm calculates the average expression stability ( $M$-value) using raw non-normalized expression values, which gives the average pairwise variation $\left(V_{n} / V_{n+1}\right)$ of expression of a particular gene in relation to all candidate reference genes. According to this software, the gene with the lowest $M$-value is considered the most stable. Using an $M$ value below the threshold of 1.5 was initially recommended 


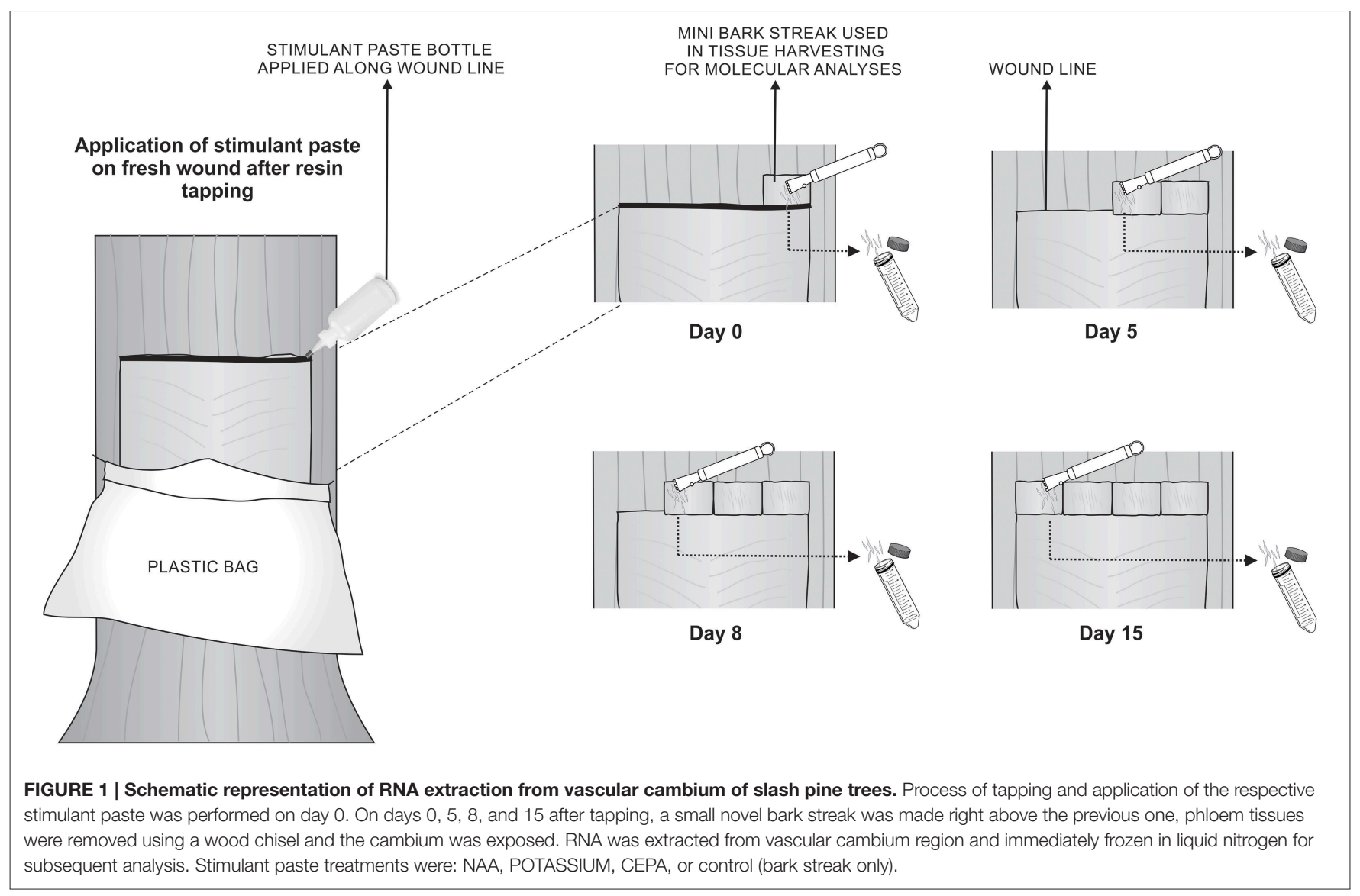

(Vandesompele et al., 2002), although a maximum value of 0.5 has been proposed for more accurate results whenever possible (Hellemans et al., 2007; Gutierrez et al., 2008). Genes with the lowest $M$-values have the most stable expression. In addition, geNorm software calculates the minimal number of reference genes required for normalization based on the geometric mean of their final optimal set. A pairwise variation of 0.15 is accepted as cut-off (Vandesompele et al., 2002), below which the inclusion of an additional control gene is not required for reliable normalization.

NormFinder has an algorithm that uses raw non-normalized data in the form of expression values generated using the comparative $C_{\mathrm{q}}$ method. It enables estimation of the overall variation of the reference normalization genes and the variation between subgroups of the sample set, taking into account intraand intergroup variations for normalization factor calculations. Genes with lowest values are considered the most stable and are top ranked. Similarly to the geNorm method, NormFinder reveals a score of expression stability to each gene, which is negatively correlated with the stability of gene expression (Andersen et al., 2004). The best candidate will be the one with the closest to zero inter-group variation, and, at the same time, having the smallest error bars.

Bestkeeper uses raw data $\left(C_{\mathrm{q}}\right.$-values $)$ and PCR efficiency and ranks the stability of candidate reference genes by performing a statistical analysis of the $C_{\mathrm{q}}$-values based on three variables: Pearson correlation coefficient (r), standard deviation (SD) and percentage covariance $(\mathrm{CV})$. In this case, any studied gene with the SD higher than 1 is considered inconsistent and should be excluded.

\section{Validation of Reference Genes}

To further confirm the reliability of the potential reference genes, the relative expression profiles of four genes involved in mono, di and sesquiterpene biosynthesis in pines were examined. Expression profiles of putative P. elliottii orthologs (herein referred to as "like-genes"-Table S1) of resin biosynthesis-related genes encoding $P$. contorta $\beta$-pinene synthase $((-) \beta$ pinS1-like; Hall et al., 2013a), P. taeda $\alpha$ pinene synthase $((+) \alpha$ pinS-like; Phillips et al., 2003), $P$. contorta levopimaradiene/abietadiene synthase (LAS1-like; Hall et al., 2013b), and P. taeda $\alpha$-farnesene synthase ( $\alpha$ FS-like; Phillips et al., 2003) were examined following stimulant paste application. In these analyses, the normalization of expression data was carried out using the most stable genes identified in this study.

The qPCR amplification conditions were the same as described above. Relative expression levels of the target gene were calculated with the $2^{-\Delta \mathrm{Cq}}$ method (Livak and Schmittgen, 2001). Values shown represent the average of three biological replicates.

The analyses covered three time points (5, 8, 15 days after wounding) and three different treatments with stimulant pastes (NAA, POTASSIUM, and CEPA), besides the control (bark streak only). 
TABLE 2 | Description of candidate reference genes, primers, and amplicons for internal control gene selection in P. elliottii.

\begin{tabular}{|c|c|c|c|c|c|}
\hline Gene & Function & $\begin{array}{l}\text { Primer sequence } \\
\left(5^{\prime}-3^{\prime}\right) \\
\text { (forward/reverse) }\end{array}$ & $\begin{array}{l}\text { Amplicon } \\
\text { length } \\
\text { (bp) }\end{array}$ & $\begin{array}{l}\text { Amplification } \\
\text { efficiency }\end{array}$ & $\begin{array}{l}\text { GenBank } \\
\text { accession } \\
\text { number or } \\
\text { Reference }\end{array}$ \\
\hline ACT (actin) & $\begin{array}{l}\text { Structural constituent of } \\
\text { cytoskeleton, ATP binding }\end{array}$ & $\begin{array}{l}\text { CACTGCACTTGCTCCCAGTA } \\
\text { GGTCTTGGCAATCCACATCT }\end{array}$ & 130 & 1.961 & AY172979 (Pt) \\
\hline AK (adenosine kinase) & $\begin{array}{l}\text { Phosphotransferase activity, } \\
\text { cysteine biosynthesis }\end{array}$ & $\begin{array}{l}\text { ATCTITAGGGCTATITCTTC/ } \\
\text { TTACT } \\
\text { GAGGCATTGATGA }\end{array}$ & 127 & 1.845 & $\begin{array}{l}\text { de Vega-Bartol } \\
\text { et al., } 2013\end{array}$ \\
\hline ATUB ( $\alpha$-tubulin) & $\begin{array}{l}\text { Structural constituent of } \\
\text { cytoskeleton, microtubule-based } \\
\text { processes }\end{array}$ & $\begin{array}{l}\text { CCGTाTTTCGCAGTाITC/ } \\
\text { CAAGCATITCCAACCTGGAT }\end{array}$ & 119 & 1.878 & KF158848 (Pt) \\
\hline CYP (cyclophilin) & $\begin{array}{l}\text { Protein folding and trafficking, } \\
\text { pre-mRNA splicing, extracellular } \\
\text { signaling molecules }\end{array}$ & $\begin{array}{l}\text { TGCAAAGACAGAGTGGTTGG/ } \\
\text { GCAATAACTACGGGCTTGGA }\end{array}$ & 129 & 1.870 & EF532602 (Pt) \\
\hline eEF (elongation factor) & Translational elongation & $\begin{array}{l}\text { ACAACCACTGGGCATTTGAT/ } \\
\text { ACGTTCAGCCTTGAGCTTGT }\end{array}$ & 138 & 1.866 & FN256567 (Pp) \\
\hline $\begin{array}{l}\text { elF4A/l (translation } \\
\text { initiation factor } 4 \text { All) }\end{array}$ & $\begin{array}{l}\text { Mediates the recruitment of } \\
\text { ribosomes to mRNA, delivery of } \\
\text { an RNA helicase to the } 5^{\prime} \text { region } \\
\text { of the mRNA }\end{array}$ & $\begin{array}{l}\text { ATTCAGGTGGGTGTाTCTCT/ } \\
\text { GTGTGATTGCCAGGGTCTC }\end{array}$ & 202 & 1.943 & $\begin{array}{l}\text { Gonçalves et al., } \\
2005\end{array}$ \\
\hline $\begin{array}{l}\text { HEATS (homologous to a } \\
\text { heat shock protein) }\end{array}$ & $\begin{array}{l}\text { Response to heat and high light, } \\
\text { protein folding }\end{array}$ & $\begin{array}{l}\text { GGCAGAATACAAGAATGG/ } \\
\text { TTGAAGTTCCGTCAGTTA }\end{array}$ & 120 & 1.944 & $\begin{array}{l}\text { de Vega-Bartol } \\
\text { et al., } 2013\end{array}$ \\
\hline HISTO3 (histone 3) & $\begin{array}{l}\text { Cell proliferation, DNA Binding, } \\
\text { RNA methylation }\end{array}$ & $\begin{array}{l}\text { GCTGAGGCTTACCTTGTG/ } \\
\text { CCAGTTGTATATCCTT } \\
\text { AGGCATAA }\end{array}$ & 94 & 1.877 & $\begin{array}{l}\text { de Vega-Bartol } \\
\text { et al., } 2013\end{array}$ \\
\hline $\begin{array}{l}\text { REDUC (homologous to } \\
\text { a ether reductase protein) }\end{array}$ & $\begin{array}{l}\text { Ether reductase protein, } \\
\text { response to cadmium }\end{array}$ & $\begin{array}{l}\text { AGGAAGACATTGGAACATT/ } \\
\text { CAGAGTATTGGCAGGAAG }\end{array}$ & 92 & 1.878 & $\begin{array}{l}\text { de Vega-Bartol } \\
\text { et al., } 2013\end{array}$ \\
\hline SAND (SAND protein) & $\begin{array}{l}\text { Intracellular vesicular transport, } \\
\text { biogenesis, and vacuole } \\
\text { signaling }\end{array}$ & $\begin{array}{l}\text { GATCGTGGAGCAATITGG/ } \\
\text { TTATCGACATATCATCCTCATT }\end{array}$ & 86 & 1.832 & $\begin{array}{l}\text { de Vega-Bartol } \\
\text { et al., } 2013\end{array}$ \\
\hline UBI (ubiquitin) & $\begin{array}{l}\text { Signaling complexes for protein } \\
\text { degradation, translation control, } \\
\text { DNA repair, endocytosis } \\
\text { regulation, protein traffic }\end{array}$ & $\begin{array}{l}\text { GATाTATTCATTGGCAGGC/ } \\
\text { AGGATCATCAGGATITGGGT }\end{array}$ & 149 & 1.870 & $\begin{array}{l}\text { de Vega-Bartol } \\
\text { et al., } 2013\end{array}$ \\
\hline
\end{tabular}

Pt, P. taeda; Pp, P. pinaster.

All amplicons of both reference and TPS genes were sequenced to confirm correct identity.

\section{Statistical Analyses}

Experiments were conducted in completely randomized layout. Results were analyzed by ANOVA followed by Tukey test or Welch ANOVA followed by Dunnett's C test (between time points within each treatment) or $t$-test (between treatments within each time point), whenever appropriate, using the statistic package SPSS 20.0 for Windows (SPSS Inc., USA). A $P \leq 0.05$ was used in all cases. Data were expressed as mean \pm standard error (S.E.).

\section{RESULTS}

\section{Resin Yield Induced by Different Stimulant Paste Treatments}

Estimated resin biomass exuded per streak was significantly increased in all of the trees treated with resin-stimulant paste compared to the non-stimulated control trees. Although CEPA treated trees produced more resin that those treated with POTASSIUM, overall yields of trees stimulated with the different pastes were very similar (Figure S1).

\section{Description and Expression Profile of the Candidate Reference Genes}

Total RNA isolated from the 48 samples (including biological replicates) had high quality. Specificity of the primers was confirmed by agarose gel electrophoresis and melting curve analysis (Figure S2). Sequencing of amplicons confirmed the identity of all candidate reference genes (data not shown). Amplification efficiencies of PCRs ranged from 1.832 for SAND to 1.961 for ACT (Table 2). These numbers provided a good basis for further validation of reference genes.

The expression level of the genes tested was different. In qPCR, considering all time point values, the reference genes reached mean $C_{q}$-values (i.e., number of cycles needed for the amplification- related fluorescence to reach threshold level of detection) ranging from 21 to 32, most lying between 22 and 26. CYP (mean $C_{\mathrm{q}} \pm$ S.E. $=21.85 \pm 0.25$ ) was the most expressed 
gene and $S A N D\left(\right.$ mean $C_{\mathrm{q}} \pm$ S.E. $=32.73 \pm 0.33$ ) the least. The expression profiles of all candidate reference genes along the different treatments tested are shown in Figure 2.

\section{Expression Stability of Candidate Genes}

Three different approaches implemented in geNorm, Normfinder, and Bestkeeper programs were used to determine the expression stability of each candidate gene in comparison to the other candidate genes. Overall, the rankings generated by the three programs were consistent.

\section{geNorm}

Under different treatment conditions and throughout the sampling period, 10 reference genes showed high expression stabilities with threshold values below 1.5. The exception was the $A K$ gene $(M=1.65)$, which was disregarded for further analysis. Among those genes with $M$ values below 1.5, HEATS $(M=1.28)$ was the least stable gene and HISTO3 and UBI $(M=0.57)$ were identified as the best pair of reference genes (Figure 3A).

To generate accurate and reliable results, geNorm algorithm finds the optimal number of suitable reference genes required for proper normalization by step wise calculation of the pairwise variation $\left(\mathrm{V}_{\mathrm{n}} / \mathrm{V}_{\mathrm{n}+1}\right)$ between two sequential normalization factors, which measures the effect of increasing reference genes required for normalization. Considering the reference value of 0.15 proposed by Vandesompele et al. (Vandesompele et al., 2002), both V6/7 and V7/8 reach it, indicating that six reference genes are required for normalization of gene expression analyses. However, V5/6 showed an acceptable value (0.153), suggesting that five reference genes may also suffice for expression analyses (Figure 3B).

\section{NormFinder}

Results from this software highlighted $U B I$ as the best reference gene (stability value $=0.34$ ), and ranked CYP $(0.42)$ and HISTO3 (0.49) in the second and third positions, respectively, whereas HEATS and $A K$ were scored as the least stable genes (Table 3). Nevertheless, results showed UBI and HISTO3 at the forefront of the ranking, indicating a good agreement between the results of NormFinder and geNorm for the data set.

\section{BestKeeper}

BestKeeper was also used to calculate and compare gene expression variation for the candidate reference genes based on their pair-wise correlation with an index value, which is indicated

TABLE 3 | Ranking of candidate reference genes in P. elliottii in decreasing order of expression stability calculated by NormFinder software.

\begin{tabular}{ll}
\hline Ranking order & NormFinder (stability value \pm S.E.) \\
\hline 1 & UBI $(0.34 \pm 0.03)$ \\
2 & CYP $(0.42 \pm 0.09)$ \\
3 & HISTO3 $(0.49 \pm 0.20)$ \\
4 & SAND $(0.50 \pm 0.22)$ \\
5 & ACT $(0.55 \pm 0.10)$ \\
6 & EEF $(0.63 \pm 0.15)$ \\
7 & eIF4II $(0.69 \pm 0.17)$ \\
8 & ATUB $(0.88 \pm 0.39)$ \\
9 & REDUC $(0.91 \pm 0.50)$ \\
10 & HEATS $(0.97 \pm 0.57)$ \\
11 & AK $(1.93 \pm 0.68)$
\end{tabular}

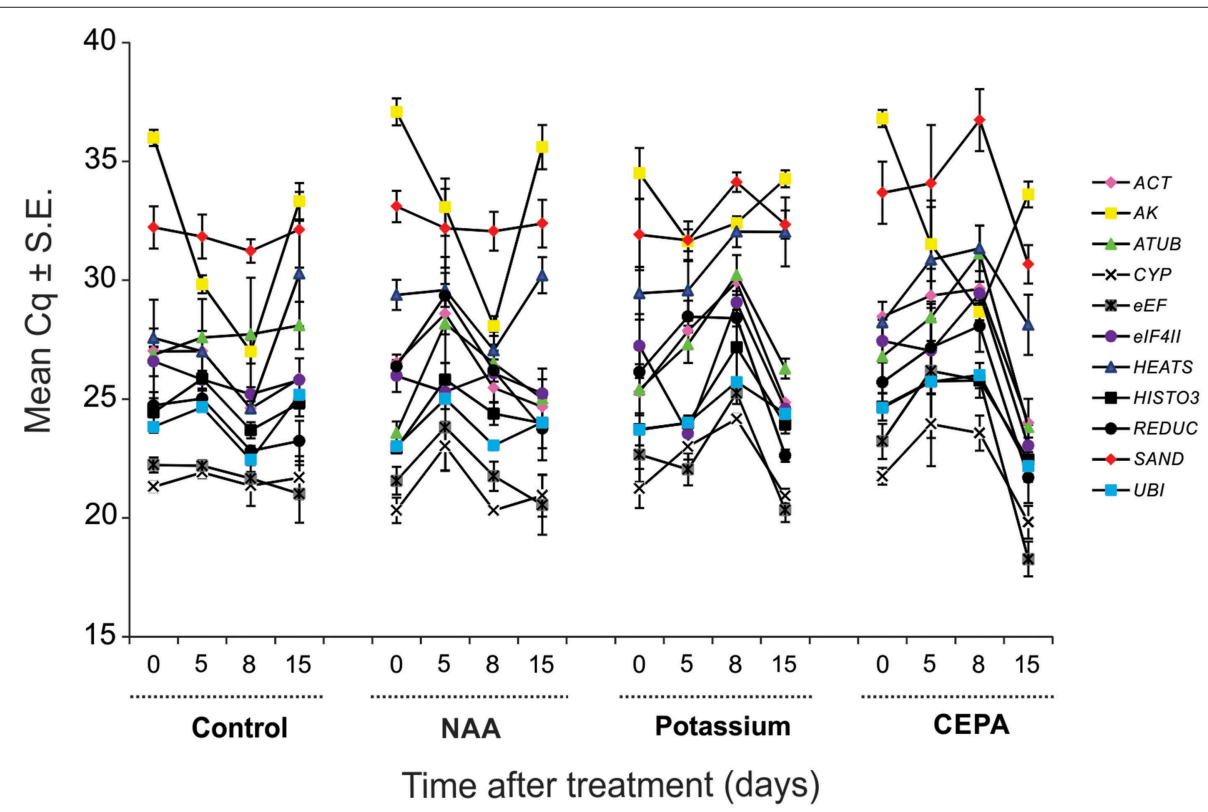

FIGURE 2 | Expression of tested reference genes along the different treatments and days of analysis presented as Cq mean value \pm standard error (S.E.). Legend: pink diamond (ACT), yellow square (AK), green triangle (ATUB), white "X" mark-(CYP), gray "X" mark: (eEF), purple circle-(eIF4II), blue triangle (HEATS), dark square: (HISTO3), dark circle: (REDUC), red diamond: (SAND), and blue square: (UBI). 


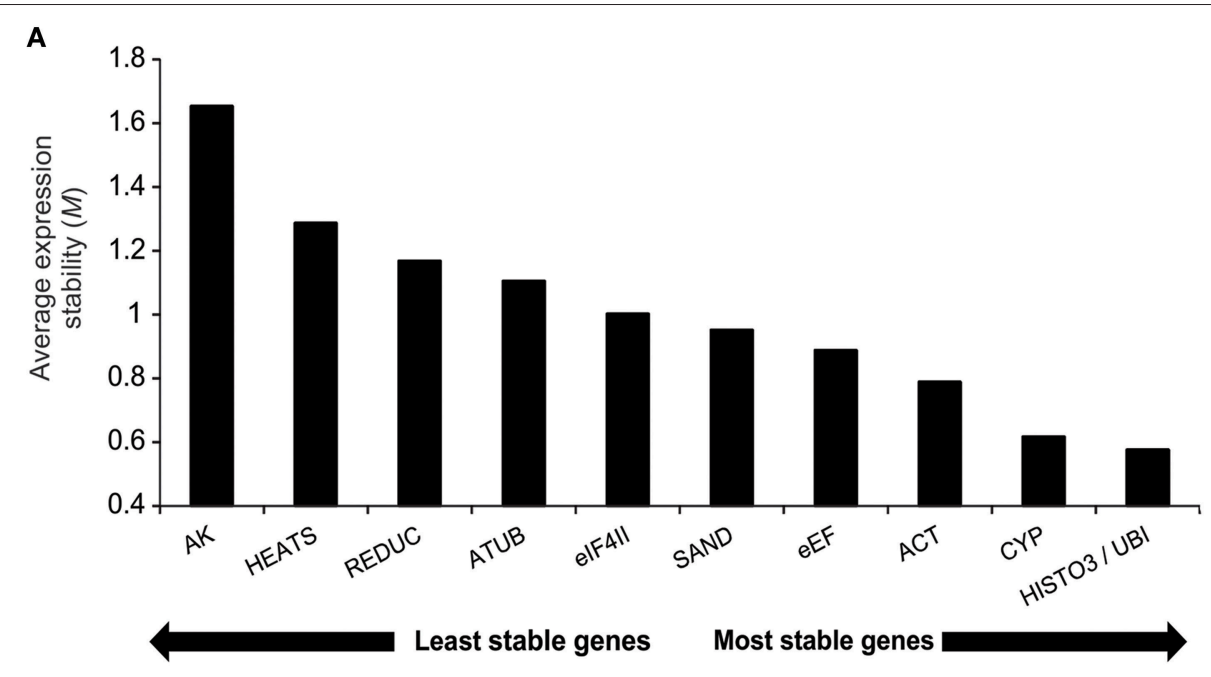

B

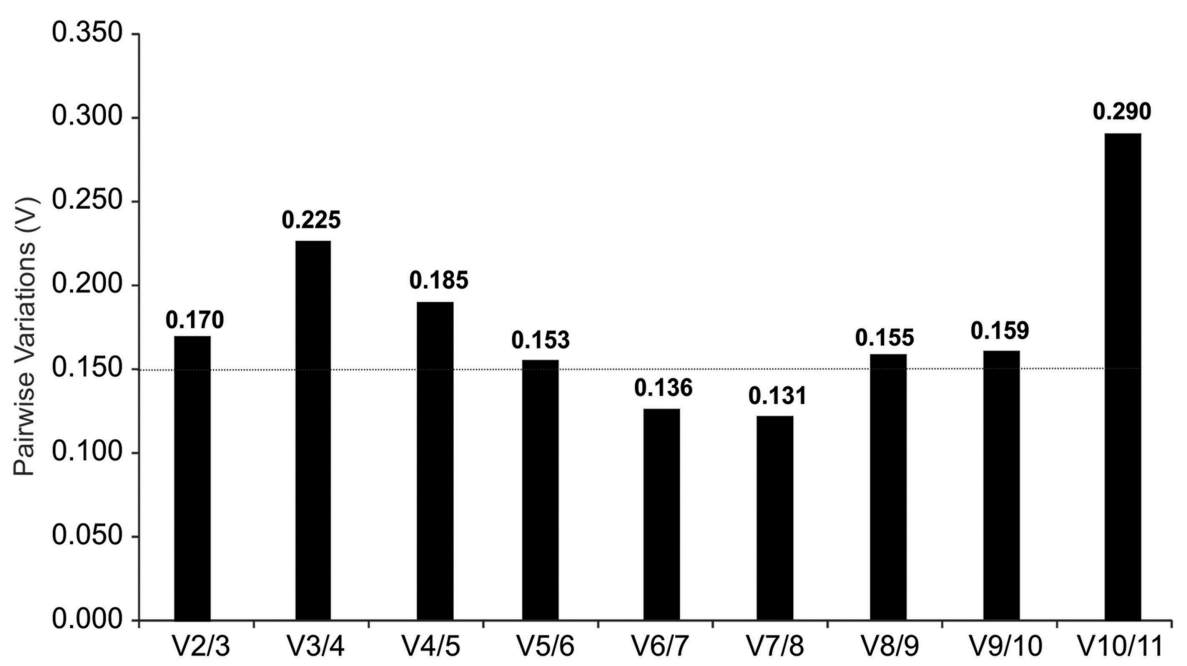

FIGURE 3 | geNorm descriptive analyses during oleoresinosis in $\boldsymbol{P}$. elliottii. (A) Average expression stability ( $M$ ) and ranking of the 11 reference genes. A lower average expression stability $M$ value indicates more stable expression. (B) Pairwise variation of the candidate genes. The pairwise variation (Vn/ $\mathrm{n}+1)$ was calculated between the normalization factors NFn and NFn+1, with a recommended cut-off threshold of 0.150 .

by the Pearson correlation coefficient $(r)$. BestKeeper calculates the standard deviation (SD) and the coefficient of variation (CV) based on the raw $C_{\mathrm{q}}$-values of each gene. Because the maximum number of genes analyzed by this algorithm is 10 (Pfaffl et al., 2004), the candidate gene $A K$ was excluded from the analyses, since it ranked lower in the previous analyses (geNorm and NormFinder). The most stable reference genes exhibit the lowest $\mathrm{CV}$ and SD and highest $r$. Genes with SD higher than 1 should be considered inconsistent. Only two genes, UBI and HISTO3, had $S D \leq 1$ and thus could be considered to be stably expressed. Regarding these two genes, BestKeeper recommended UBI as the most stable gene with the highest correlation coefficient (0.893) and lowest CV [\% $C_{\mathrm{q}}$ ] (4.01). The second most stable gene was HISTO3, with an $r$ of 0.869 and $\mathrm{CV}$ of 4.09 . The comparison of the eight other candidate reference genes was based on their $r$-value and resulted in a ranking as follows, from the most stable to the least stable: $A C T>e E F>C Y P>A T U B>S A N D>$ REDUC $>$ EIF4II $>$ HEATS. The complete ranking is depicted on Table 4. These results were essentially consistent with those obtained using geNorm and NormFinder.

\section{Reference Gene Validation}

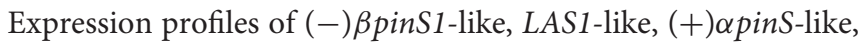
and $\alpha$ FS-like genes were examined following resin stimulant paste application. The best pair of reference genes identified (UBI and HISTO3) was used as normalizer. The analyses covered three time points $(5,8,15$ days after treatment) and three different treatments with stimulant paste (NAA, POTASSIUM and, CEPA), besides the control (bark streak only). Sequencing 
TABLE 4 | BestKeeper descriptive statistical analyses of 10 reference genes of vascular cambium in $P$. elliottii during oleoresinosis, $n=48$ (total number of samples).

\begin{tabular}{|c|c|c|c|c|c|c|c|c|c|c|}
\hline \multirow[t]{2}{*}{ Factors } & \multicolumn{10}{|c|}{ Stability of reference genes } \\
\hline & $A C T$ & ATUB & CYP & $e E F$ & elF4II & HEATS & HISTO3 & REDUC & SAND & $U B I$ \\
\hline $\mathrm{SD}[ \pm \mathrm{Cq}]$ & 1.66 & 1.53 & 1.10 & 1.64 & 1.35 & 1.53 & 0.99 & 1.98 & 1.19 & 0.99 \\
\hline CV [\% Cq] & 6.20 & 5.66 & 5.04 & 7.28 & 5.17 & 5.25 & 4.09 & 7.70 & 3.62 & 4.01 \\
\hline$r$-value & 0.946 & 0.817 & 0.915 & 0.945 & 0.787 & 0.548 & 0.869 & 0.793 & 0.814 & 0.893 \\
\hline$P$-value & 0.001 & 0.001 & 0.001 & 0.001 & 0.001 & 0.001 & 0.001 & 0.001 & 0.001 & 0.001 \\
\hline Ranking & 3 & 6 & 5 & 4 & 9 & 10 & 2 & 8 & 7 & 1 \\
\hline
\end{tabular}

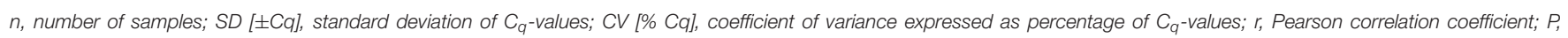
probability value. The highest $r$-values and SDs lower than 1 have been highlighted in bold.

of amplicons confirmed identity of all TPS genes. (-)BpinS1like mRNA expression remained stable after 5 and 8 days, but increased significantly after 15 days in CEPA-treated trees. At this time, expression in CEPA-treated trees was higher than that of the control treatment (Figure 4A). For the other treatments, (-) $\beta$ pinS1-like expression was essentially the same throughout the time course evaluated. Potassium-treated trees had lower expression of $(-) \beta$ pinS1-like compared to control in day 5 .

Expression of $(+) \alpha p i n S$-like gene also showed increases in expression at later time points, particularly for NAA and CEPAtreated trees (Figure 4B). CEPA-treated trees had a peak in day 8 , whereas NAA-treated ones reached a maximum in day 15 . At this time, expression of $(+) \alpha p i n S$-like in NAA-treated trees was significantly higher than in the corresponding control treatment (Figure 4B). As seen for the (-)BpinS1-like gene, expression of $(+)$ apinS-like in potassium-treated trees was lower compared to the corresponding controls in days 5 and 8 .

Expression of LAS1-like gene increased over time, peaking at 15 days for all treatments. Significant increases throughout the time course were observed for NAA and potassium-treated plants (Figure 4C). However, there were no differences of treatments within time points in relation to control plants, except for decrease in potassium treatment in days 5 and 8 . Compared to the pinene synthase-like genes, LAS1-like gene expression was considerably lower, between one and two orders of magnitude (Figure 4).

The $\alpha F S$-like gene expression was only consistently detected in day 15 , all treatments being equivalent in level of expression. This gene also showed relatively low expression in days 5 and 8 , ranging from 0.05 to 0.06 (data not shown).

\section{DISCUSSION}

The selection of appropriate housekeeping genes is a crucial requisite to successful gene expression profiling based on qPCR. The use of inaccurate reference genes can lead to inconsistent results, particularly when variations in the rate of transcription are small between sample groups (Dheda et al., 2005; Etschmann et al., 2006). Ideal reference gene(s) should exhibit relatively constant levels of RNA steady-state in all tissues/cells or organs and should not be regulated or influenced by the experimental procedures (Radonić et al., 2004; Guenin et al., 2009). Nevertheless, ideal reference genes for all tissues, biological conditions and treatments may be difficult to establish, for the expression of a putative reference gene may vary among the several possible biological situations.

Eleven putative reference genes were selected for expression studies on P. elliottii oleoresinosis based on previous reports that indicated them as suitable genes for normalization of expression profiles in different species and in relation to other biological processes (Gonçalves et al., 2005; Wang et al., 2010; de VegaBartol et al., 2013). Those 11 candidates were evaluated to find the best set of stable gene normalizers to check gene expression associated with resinosis under the effect of alternative chemical elicitors at different time periods after initial bark wounding. Expression stability was evaluated by three different softwares (geNorm, NormFinder, and BestKeeper), enabling a more reliable analysis considering the gene expression data. HISTO3 and UBI were identified as the top reference genes using geNorm and BestKeeper, whereas NormFinder ranked HISTO3 in the third ranking position, ranking $U B I$ and $C Y P$ as the most stable genes. In spite of some minor inconsistencies that are usually observed between these different methods (Gonçalves et al., 2005; Lin and Lai, 2010; Morgante et al., 2011; Chang et al., 2012; Liu et al., 2014), our results were quite consistent regardless of the algorithm employed.

Several studies have shown that the application of more than one reference gene can provide greater accuracy in qPCR experiments with plants (Vandesompele et al., 2002). To determine the optimal number of reference genes required for accurate normalization, the geNorm software calculates the pairwise variation $(\mathrm{Vn} / \mathrm{Vn}+1)$ between the sequential normalization factors. Our results indicated five to six as the ideal number of housekeeping genes, which would increase significantly the experimental costs. However, a number of other studies using this application have resulted in higher pairwise variations (De Ketelaere et al., 2006; Hong et al., 2008; Jian et al., 2008; Fernandez et al., 2011; Han et al., 2012; Kong et al., 2014). The geNorm threshold lower than 0.15 is not a strict cutoff but an ideal value to provide guidance in determining the optimal number of reference genes, also requiring an analysis of the trend of changing pairwise variation values (Hong et al., 2008). Depending on the specific conditions of the study, the optimal number of stable controls that should be used for 
A

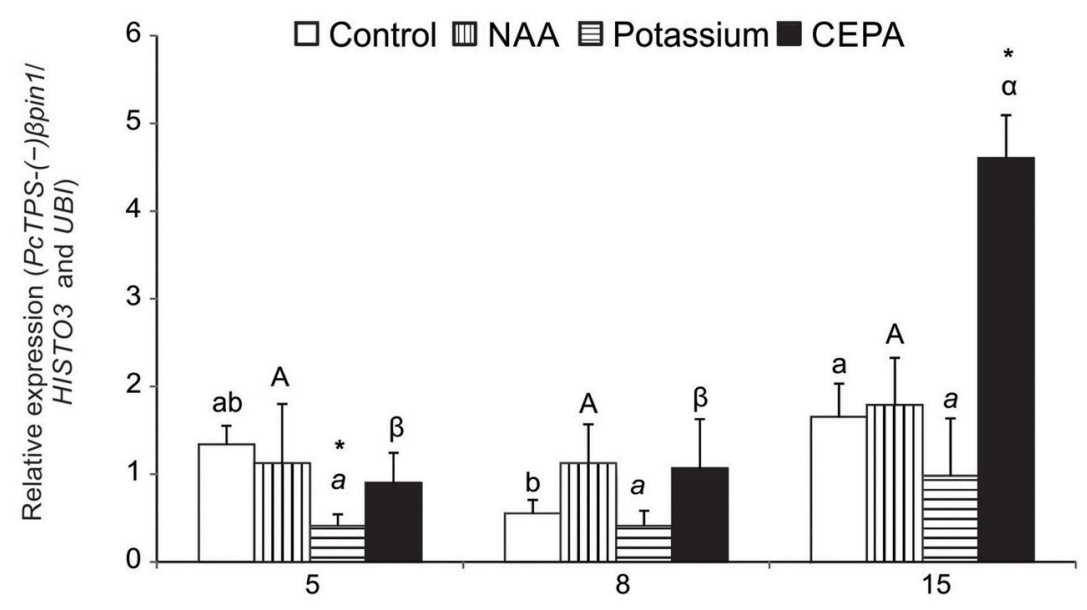

B

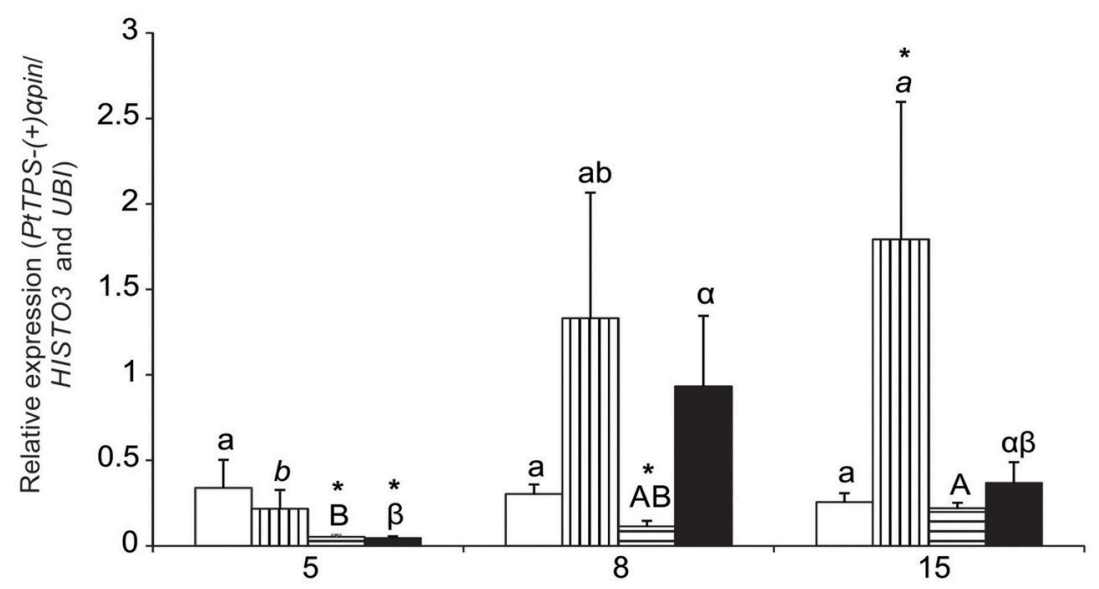

C

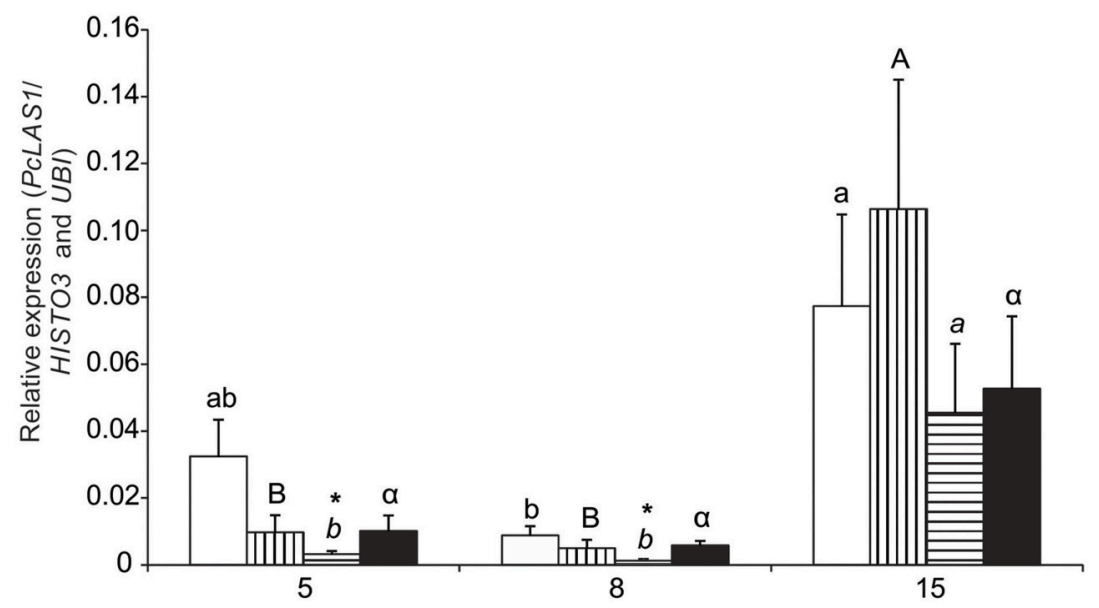

FIGURE 4 | Relative expression profile of target genes during oleoresinosis in $\boldsymbol{P}$. elliottii 5, 8, and 15 days after treatment. (A)(-) $\beta$ pinS1-like; (B) (+)apinS-like;(C) LAS1-like.The expression profile of the target genes was investigated relative to the best combination of reference genes indicated by geNorm, NormFinder, and BestKeeper softwares (HISTO3 and UBI). Different lowercase, uppercase, italic, and Greek letters indicate significant difference among the samples of control, NAA, potassium, and CEPA, respectively, by Tukey test or Dunnett's $C$ test $(P \leq 0.05)$. *Indicates that the treatment was significantly different compared to control (bark streak only, with no resin stimulant paste) within the respective time point by $t$-test $(P \leq 0.05)$. 
normalization against the target genes has to be modified. In the present study, the experiments were performed in the field, with environmental conditions not subject to control and using individuals derived from seeds, hence with distinct genetic characteristics. Therefore, we suggest that two reference genes (HISTO3 and UBI) are sufficient to normalize samples, since the $\mathrm{V} 2 / 3$ value was relatively close to $0.15(\mathrm{~V} 2 / 3=0.17)$ and the stepwise addition of a third reference gene did not result in decrease of the $\mathrm{V}$ value closer to $0.15(\mathrm{~V} 3 / 4=0.22)$ (Figure 3B).

The high expression stability showed in our experiments for HISTO3 and UBI corroborates data from Tu et al. (2007) in a study with cotton (Gossypium hirsutum L.). The expressions of HISTO 3, UBI 7 and Gbpolyubiquitin-1 were the most stable during cotton fiber development and somatic embryogenesis. Wang et al. (2013) also selected ubiquitin as one of the most reliable reference gene for gene expression under abiotic stress in cotton, and the same result was also previously seen in other species (Hong et al., 2008; Løvdal and Lillo, 2009; Morgante et al., 2011; Monteiro et al., 2013).

The use of qPCR to examine reference gene expression in conifers is still very limited. To date, studies of normalizing genes in conifers have focused on somatic embryogenesis (Gonçalves et al., 2005; de Vega-Bartol et al., 2013). Expression profiles of four candidate reference genes have been examined in maritime pine (P. pinaster) during embryogenesis: GAPDH, 18S, eIF4AII, and UBI (Gonçalves et al., 2005). However, high variability of the four genes tested ruled out their use as internal standards for qPCR in this developmental process.

De Vega-Bartol et al. (2013) analyzed internal control genes during different steps of somatic embryogenesis in $P$. pinaster and $P$. abies (embryonal mass proliferation, embryo maturation and germination). The best combination for $P$. pinaster included three genes: EF1, ATUB, and HISTO3. For $P$. abies, four genes were necessary for normalization: ATUB, $A K$, $C A C$, and EF1. However, authors discuss that more accurate results were obtained when each developmental stage was analyzed separately. In spite of the reported developmental stage dependence found in these studies, our results on $P$. elliottii resinosis concerning the use of HISTO3 as suitable housekeeping gene is in good agreement with $P$. pinaster embryogenesis expression data. This could be an indication that HISTO3 may represent a useful option to be considered in other conifer studies.

The oleoresin synthesized by Pinus is a major source of terpenes, which are biosynthesized by TPS mostly in the cambium zone and associated with vascular tissues. Oleoresin is a well-established defense product in conifers and its biosynthesis may be modulated, at least in part, by wounding and/or chemical stimuli (Rodrigues-Corrêa and Fett-Neto, 2012). Chemical treatments in addition to wounding have been used as an economic strategy explored in resin tapping operations, as a result of the improvement in resin exudation (Rodrigues-Corrêa and Fett-Neto, 2012; Rodrigues-Corrêa et al., 2013).

Various genes encoding TPS have been already isolated and characterized from conifer species (Rodrigues-Corrêa et al., 2013). Four different resin biosynthesis-related genes were evaluated as targets during resin extraction under field conditions for validating the best normalizers identified in the present study (UBI and HISTO3), as determined by geNorm, NormFinder and BestKeeper softwares. Expression profiles of P. elliottii orthologs of $\beta$-pinene (PcTPS- $(-) \beta$ pin 1), levopimaradiene/abietadiene (PcLAS1) synthase, $\alpha$-pinene synthase (PtTPS- $(+) \alpha$ pin), and $\alpha$ farnesene synthase $(P t \alpha F S)$ genes were examined following resin stimulant paste application.

Taken together, the main results for expression profiles of the resin biosynthesis-related target genes used in reference gene validation may be summed up as follows: (1) higher expression levels of all genes were observed at later time

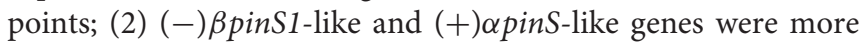
expressed than those of LAS1-like and $\alpha F S$-like genes; (3) significantly higher expression relative to control trees was observed in phytohormone (NAA and CEPA)-stimulated trees, which correlated well with higher resin yields; (4) in spite of its capacity to increase resin yield, potassium-based pastes had almost no stimulatory effect on gene expression.

The kinetics of gene expression showing an increase at later time points is in agreement with the general practice of bark streaking every 15 days, since this would ensure a reactivation of the wound responses that lead to resin production and flow (Rodrigues et al., 2008). P. elliottii trees had an increase in monoterpene biosynthesis after 2 weeks of wounding (Popp et al., 1995b). The accumulated biosynthesized resin from the last streak likely flows during the first days after the current streak. In fact, it is commonly observed under field conditions that resin flow is more intense following bark streaking. Presumably, paste stimulants could induce new resin biosynthesis predominantly at transcript level in later time points during the current streak and enzyme activity at earlier periods in the following streak.

The higher expression of $(-) \beta$ pinS1 and $(+) \alpha p i n S$-like genes compared to LAS1-like and $\alpha F S$-like genes within the time frame evaluated is consistent with reported changes in gene expression and enzyme activity for Abies grandis after wounding, in which higher gene expression (Northern blot data) and TPS activity were determined for monoterpene synthases (Trapp and Croteau, 2001). In P. contorta and Pinus banksiana successive bark punches ( $10 \mathrm{~mm}$ diameter) at zero, 2 and 14 days resulted in increased pinene amounts in exuded resin after 2 and 14 days (Clark et al., 2014). Increased monoterpene synthase gene expression was found in Picea sitchensis with a peak of expression between 7 and 16 days post-wounding (Byun-McKay et al., 2006). Transcriptomic studies detected that high level of expression of a monoterpene synthase was associated with increased resin production in 27 year-old bark streaked trees of Pinus massoniana not treated with stimulant paste (Liu et al., 2015). Although these various patterns of gene expression and terpene production are not from the same species and experimental conditions, they may reflect a highly conserved mechanism of response to damage in conifers. Indeed, well-established chemical stimulants of slash pine resinosis were effective in inducing resin exudation in saplings of a rather primitive gymnosperm that has resin canals only in its bark, Araucaria angustifolia (Perotti et al., 2015). 
Up-regulation of $(-) \beta$ pinS1 and $(+) \alpha p i n S$-like was recorded in plants chemically stimulated with CEPA. CEPA is an ethylenereleasing compound and one of the main oleoresin stimulators (McReynolds and Kossuth, 1984). The effect of this compound includes increased biosynthesis of mono and diterpenes in other conifers (Croteau et al., 1987; Popp et al., 1995a,b; Katoh and Croteau, 1998), in good agreement with the results obtained in this study.

Chemical stimulation with NAA also induced increased expression of $(+) \alpha p i n S$-like. Auxin can indirectly affect the yield of oleoresin, probably by stimulating the production of ethylene by promoting transcription activation of 1-aminocyclopropane1-carboxylate synthase (ACS) genes involved in ethylene biosynthesis (Chae and Kieber, 2005) and also by increasing the differentiation of vertical resin ducts (Fahn, 1982). Previous results examining production over a full year showed higher resin yields in plants treated with stimulant paste supplemented with the synthetic auxin 2-4-D (2,4-dichlorophenoxyacetic acid) when compared to control (only bark streak) (Rodrigues and FettNeto, 2009). Results of the present study suggest this effect may be at least in part due to increased transcription of a monoterpene synthase gene.

Results with $P$. abies and $P$. contorta showed that potassium takes part in the catalytic mechanism of monoterpene synthases, improving their activity (Savage et al., 1994; Trapp and Croteau, 2001). Previous results with potassium sulfate stimulant paste (500 mM) in P. elliottii showed an improvement of pine oleoresin yields when compared to control (Rodrigues et al., 2011). Considering the catalytic role of the metal, which takes place at post-translational level, increased transcript accumulation is not expected with potassium stimulant paste. The limited increases in quantitative gene expression data and the higher yields of resin biomass obtained in the present study with potassium-based paste are in good agreement with this expectation. The lower levels of gene expression observed for potassium paste-treated trees at some time points perhaps could reflect reduced need for transcriptional stimulation as a function of higher enzyme activation.

The absence of major and widespread differences regarding control and stimulated expression in the four target genes examined indicates that probably other levels of regulation of resin biosynthesis are important. These regulatory points may include enzyme activity, protein stability and modification, subcellular compartmentalization, metabolic channeling dynamics, metabolite transport, and substrate availability, all of which are known as being relevant forms of plant secondary metabolism control (Nascimento and Fett-Neto, 2010).

To our knowledge, this is the first systematic analysis for the selection of validated reference genes for $\mathrm{qPCR}$ in vascular

\section{REFERENCES}

Andersen, C. L., Jensen, J. L., and Orntoft, T. F. (2004). Normalization of realtime quantitative reverse transcription-PCR data: a model-based variance estimation approach to identify genes suited for normalization, applied cambium tissue of field-grown adult individuals of conifers under resin tapping operation, and the first demonstration of increased terpene synthase gene expression during oleoresinosis in slash pine. Our shortlist of reference genes may provide a useful tool to find normalizers for experiments that address other variables and physiological conditions in Pinus.

\section{AUTHOR CONTRIBUTIONS}

JD and FD carried out the experiments, analyzed the data, and drafted the manuscript. KR, TF, MK, and ML assisted in different parts of the experimental procedures and sample harvesting. JF revised data analyses and edited the manuscript. AF devised and supervised the study and finalized the manuscript.

\section{FUNDING}

This work was funded by the National Council for Scientific and Technological Development (CNPq-Brazil), grants 476838/20126 and 306079/2013-5.

\section{ACKNOWLEDGMENTS}

Financial support for this research was provided by Brazilian Research Agencies National Council for Scientific and Technological Development $(\mathrm{CNPq})$, Coordination for the Improvement of Higher Education Personnel (CAPES), and Rio Grande do Sul State Foundation for Research Support (Fapergs). Access to pine trees from forest stands of Irani Celulose/Habitasul Florestal is gratefully acknowledged.

\section{SUPPLEMENTARY MATERIAL}

The Supplementary Material for this article can be found online at: http://journal.frontiersin.org/article/10.3389/fpls.2016. 00849

\section{Table S1 | Description of target genes used to validate the putative reference genes.}

Figure S1 | Resin biomass yield estimated as average per streak. Data for winter season based on 80 trees per stimulant paste treatment was used to estimate average resin yield per streak (corresponding to a 15 day period). Different letters indicate significant difference between treatments by Tukey test $(P \leq 0.05)$.

Figure S2 | Specificity of qPCR. (A) Melting curves of the 11 reference genes plus target genes showing a single peak (each representing a technical triplicate). Y-axis: derivative reporter (-Rn) of the melting peak (random units); X-axis: temperature of melting; each vertical line marking the melting peak represents the medium temperature of melting between 80 and $90^{\circ} \mathrm{C}$. (B) Agarose gel showing PCR amplicons of each gene. Numbers in the gel correspond to the ones in the melting curves. DNA ladder in the gel: $100 \mathrm{bp}$. 
Brown, C. L., and Nix, L. E. (1975). Uptake and transport of paraquat in slash pine. Forest Sci. 21, 359-364.

Byun-McKay, A., Godard, K. A., Toudefallah, M., Martin, D. M., Alfaro, R., King, J., et al. (2006). Wound-induced terpene synthase gene expression in Sitka spruce that exhibit resistance or susceptibility to attack by the white pine weevil. Plant Physiol. 140, 1009-1021. doi: 10.1104/pp.105.071803

Chae, H. S., and Kieber, J. J. (2005). Eto Brute? Role of ACS turnover in regulating ethylene biosynthesis. Trends Plant Sci. 10, 291-296. doi: 10.1016/j.tplants.2005.04.006

Chang, E., Shi, S., Liu, J., Cheng, T., Xue, L., Yang, X., et al. (2012). Selection of reference genes for quantitative gene expression studies in Platycladus orientalis (Cupressaceae) using Real-Time PCR. PLoS ONE 7:e33278. doi: 10.1371/journal.pone.0033278

Clark, E. L., Pitt, C., Carroll, A. L., Lindgren, B. S., and Huber, D. P. W. (2014). Comparison of lodgepole and jackpine resin chemistry: implications for range expansion by the mountain pine beetle, Dendroctonus ponderosae (Coleoptera: Curculionidae). PeerJ. 2:e240. doi: 10.7717/peerj.240

Croteau, R., Gurkewitz, S., Johnson, M. A., and Fisk, H. J. (1987). Biochemistry of oleoresinosis: monoterpene and diterpene biosynthesis in Lodgepole pine saplings infected with Ceratocystis clavigera or treated with carbohydrate elicitors. Plant Physiol. 85, 1123-1128. doi: 10.1104/pp.85.4.1123

de Almeida, M. R., Ruedell, C. M., Ricachenevsky, F. K., Sperotto, R. A., Pasquali, G., and Fett-Neto, A. G. (2010). Reference gene selection for quantitative reverse transcription-polymerase chain reaction normalization during in vitro adventitious rooting in Eucalyptus globulus Labill. BMC Mol. Biol. 11:73. doi: 10.1186/1471-2199-11-73

De Ketelaere, A., Goossens, K., Peelman, L., and Burvenich, C. (2006). Technical Note: validation of internal control genes for gene expression analysis in bovine polymorphonuclear leukocytes. J. Dairy Sci. 89, 4066-4069. doi: 10.3168/jds.S0022-0302(06)72450-X

de Vega-Bartol, J. J., Santos, R. R., Simoes, M., and Miguel, C. M. (2013). Normalizing gene expression by quantitative PCR during somatic embryogenesis in two representative conifer species: Pinus pinaster and Picea abies. Plant Cell Rep. 32, 715-729. doi: 10.1007/s00299-013-1407-4.

Dheda, K., Huggett, J. F., Chang, J. S., Kim, L. U., Bustin, S. A., Johnson, M. A., et al. (2005). The implications of using an inappropriate reference gene for real-time reverse transcription PCR data normalization. Anal. Biochem. 344, 141-143. doi: $10.1016 / j . a b .2005 .05 .022$

Etschmann, B., Wilcken, B., Stoevesand, K., von der Schulenburg, A., and SternerKock, A. (2006). Selection of reference genes for quantitative real-time PCR analysis in canine mammary tumors using the GeNorm algorithm. Vet. Pathol. 43, 934-942. doi: 10.1354/vp.43-6-934

Fahn, A. (1982). Plant Anatomy. Oxford: Pergamon Press.

Fernandez, P., Di Rienzo, J., Moschen, S., Dosio, G. A., Aguirrezábal, L. N., Hopp, H. E., et al. (2011). Comparison of predictive methods and biological validation for qPCR reference genes in sunflower leaf senescence transcript analysis. Plant Cell Rep. 30, 63-74. doi: 10.1007/s00299-010-0944-3

Gonçalves, S., Cairney, J., Maroco, J., Oliveira, M. M., and Miguel, C. (2005). Evaluation of control transcripts in real-time RT-PCR expression analysis during maritime pine embryogenesis. Planta 222, 556-563. doi: 10.1007/s00425-005-1562-0

Guenin, S., Mauriat, M., Pelloux, J., Van Wuytswinkel, O., Bellini, C., and Gutierrez, L. (2009). Normalization of qRT-PCR data: the necessity of adopting a systematic, experimental conditions-specific, validation of references. J. Exp. Bot. 60, 487-493. doi: 10.1093/jxb/ern305

Gutierrez, L., Mauriat, M., Guénin, S., Pelloux, J., Lefebvre, J.-F., Louvet, R., et al. (2008). The lack of a systematic validation of reference genes: a serious pitfall undervalued in reverse transcription-polymerase chain reaction (RTPCR) analysis in plants. Plant Biotechnol. J. 6, 609-618. doi: 10.1111/j.14677652.2008.00346.x

Hall, D. E., Yuen, M. M. S., Jancsik, S., Quesada, A. L., Dullat, H. K., Li, M., et al. (2013a). Transcriptome resources and functional characterization of monoterpene synthases for two host species of the mountain pine beetle, lodgepole pine (Pinus contorta) and jack pine (Pinus banksiana). BMC Plant Biol. 13:80. doi: 10.1186/1471-2229-13-80

Hall, D. E., Zerbe, P., Jancsik, S., Quesada, A. L., Dullat, H., Madilao, L. L., et al. (2013b). Evolution of conifer diterpene synthases: diterpene resin acid biosynthesis in lodgepole pine and jack pine involves monofunctional and bifunctional diterpene synthases. Plant Physiol. 161, 600-616. doi: $10.1104 /$ pp. 112.208546

Han, X., Lu, M., Chen, Y., Zhan, Z., Cui, Q., and Wang, Y. (2012). Selection of reliable reference genes for gene expression studies using Real-Time PCR in tung tree during seed development. PLoS ONE 7:e43084. doi: 10.1371/journal.pone.0043084

Hellemans, J., Mortier, G., De Paepe, A., Speleman, F., and Vandesompele, J. (2007). qBase relative quantification framework and software for management and automated analysis of real-time quantitative PCR data. Genome Biol. 8:R19. doi: $10.1186 / \mathrm{gb}-2007-8-2-\mathrm{r} 19$

Hong, S.-Y., Seo, P. J., Yang, M.-S., Xiang, F., and Park, C.-M. (2008). Exploring valid reference genes for gene expression studies in Brachypodium distachyon by real-time PCR. BMC Plant Biol. 8:112. doi: 10.1186/1471-2229-8-112

Jian, B., Liu, B., Bi, Y., Hou, W., Wu, C., and Han, T. (2008). Validation of internal control for gene expression study in soybean by quantitative real-time PCR. BMC Mol. Biol. 9:59. doi: 10.1186/1471-2199-9-59

Katoh, S., and Croteau, R. (1998). Individual variation in constitutive and induced monoterpene biosynthesis in grand fir. Phytochemistry 47, 577-582. doi: 10.1016/S0031-9422(97)00422-6

Kong, Q., Yuan, J., Gao, L., Zhao, S., Jiang, W., Huang, Y., et al. (2014). Identification of suitable reference genes for gene expression normalization in qRT-PCR analysis in watermelon. PLoS ONE 9:e90612. doi: 10.1371/journal.pone.0090612

Lin, Y. L., and Lai, Z. X. (2010). Reference gene selection for qPCR analysis during somatic embryogenesis in longan tree. Plant Sci. 178, 359-365. doi: 10.1016/j.plantsci.2010.02.005

Liu, J., Wang, Q., Sun, M., Zhu, L., Yang, M., and Zhao, Y. (2014). Selection of reference genes for quantitative Real-Time PCR normalization in Panax ginseng at different stages of growth and in different organs. PLoS ONE 9:e112177. doi: 10.1371/journal.pone.0112177

Liu, Q., Zhou, Z., Wei, Y., Shen, D., Feng, Z., and Hong, S. (2015). Genomewide identification of differentially expressed genes associated with the high yielding of oleoresin in secondary xylem of Masson pine (Pinus massoniana Lamb) by transcriptomic analysis. PLoS ONE. 10:e0132624. doi: 10.1371/journal.pone.0132624

Livak, K. J., and Schmittgen, T. D. (2001). Analysis of relative gene expression data using real-time quantitative PCR and the 2(-Delta Delta $\mathrm{C}(\mathrm{T})$ ) Method. Methods (San Diego, Calif.) 25, 402-408. doi: 10.1006/meth.20 01.1262

Løvdal, T., and Lillo, C. (2009). Reference gene selection for quantitative real-time PCR normalization in tomato subjected to nitrogen, cold, and light stress. Anal. Biochem. 387, 238-242. doi: 10.1016/j.ab.2009.01.024

McReynolds, R. D., and Kossuth, S. V. (1984). CEPA in sulfuric acid paste increases oleoresin yields. South. J. Appl. For. 8, 168-172.

Monteiro, F., Sebastiana, M., Pais, M. S., and Figueiredo, A. (2013). Reference gene selection and validation for the early responses to downy mildew infection in susceptible and resistant Vitis vinifera cultivars. PLOS ONE 8:e72998. doi: 10.1371/journal.pone.0072998

Morgante, C. V., Guimaraes, P. M., Martins, A. C., Araujo, A. C., LealBertioli, S. C., Bertioli, D. J., et al. (2011). Reference genes for quantitative reverse transcription-polymerase chain reaction expression studies in wild and cultivated peanut. BMC Res. Notes 4:339. doi: 10.1186/1756-0500-4-339

Nascimento, N. C., and Fett-Neto, A. G. (2010). Plant secondary metabolism and challenges in modifying its operation: an overview. Meth. Mol. Biol. 643, 1-13. doi: 10.1007/978-1-60761-723-5_1

Perotti, J. C., Rodrigues-Corrêa, K. C. S., and Fett-Neto, A. G. (2015). Control of resin production in Araucaria angustifolia, an ancient South American conifer. Plant Biol. 17, 852-859. doi: 10.1111/plb.12298.

Pfaffl, M. W., Tichopad, A., Prgomet, C., and Neuvians, T. P. (2004). Determination of stable housekeeping genes, differentially regulated target genes and sample integrity: BestKeeper - Excel-based tool using pair-wise correlations. Biotechnol. Lett. 26, 509-515. doi: 10.1023/B:BILE.0000019559.84305.47

Phillips, M. A., and Croteau, R. B. (1999). Resin-based defenses in conifers. Trends Plant Sci. 4, 184-190.

Phillips, M. A., Wildung, M. R., Williams, D. C., Hyatt, D. C., and Croteau, R. (2003). cDNA isolation, functional expression, and characterization of (+)alpha-pinene synthase and (-)-alpha-pinene synthase from loblolly pine (Pinus 
taeda): stereocontrol in pinene biosynthesis. Arch. Biochem. Biophys. 411, 267-276. doi: 10.1016/S0003-9861(02)00746-4

Pio, C. A., and Valente, A. A. (1998). Atmospheric fluxes and concentrations of monoterpenes in resin-tapped pine forests. Atmos. Environ. 32, 683-691. doi: 10.1016/S1352-2310(97)00327-0

Popp, M. P., Johnson, J. D., and Lesney, M. S. (1995a). Changes in ethylene production and monoterpene concentration in slash pine and loblolly pine following inoculation with bark beetle vectored fungi. Tree Physiol. 15, 807-812. doi: 10.1093/treephys/15.12.807

Popp, M. P., Johnson, J. D., and Lesney, M. S. (1995b). Characterization of the induced response of slash pine to inoculation with bark beetle vectored fungi. Tree Physiol. 15, 619-623. doi: 10.1093/treephys/15.9.619

Radonić, A., Thulke, S., Mackay, I. M., Landt, O., Siegert, W., and Nitsche, A. (2004). Guideline to reference gene selection for quantitative real-time PCR. Biochem. Biophys. Res. Commun. 313, 856-862. doi: 10.1016/j.bbrc.2003. 11.177

Ramakers, C., Ruijter, J. M., Deprez, R. H., and Moorman, A. F. (2003). Assumption-free analysis of quantitative real-time polymerase chain reaction (PCR) data. Neurosci. Lett. 339, 62-66. doi: 10.1016/S0304-3940(02) 01423-4

Rodrigues, K. C. D. S., Apel, M. A., Henriques, A. T., and Fett-Neto, A. G. (2011). Efficient oleoresin biomass production in pines using low cost metal containing stimulant paste. Biomass Bioenerg. 35, 4442-4448. doi: 10.1016/j.biombioe.2011.08.021

Rodrigues, K. C. S., Azevedo, P. C. N., Sobreiro, L. E., Pelissari, P., and FettNeto, A. G. (2008). Oleoresin yield of Pinus elliottii plantations in a subtropical climate: effect of tree diameter, wound shape and concentration of active adjuvants in resin stimulating paste. Ind. Crop. Prod. 27, 322-327. doi: 10.1016/j.indcrop.2007.11.010

Rodrigues, K. C. S., and Fett-Neto, A. G. (2009). Oleoresin yield of Pinus elliottii in a subtropical climate: seasonal variation and effect of auxin and salicylic acid-based stimulant paste. Ind. Crop. Prod. 30, 316-320. doi: 10.1016/j.indcrop.2009.06.004

Rodrigues-Corrêa, K. C. D. S., and Fett-Neto, A. G. (2013). Seasonality and chemical elicitation of defense oleoresin production in field-grown slash pine under subtropical climate. Theor. Exp. Plant Physiol. 25, 56-61. doi: 10.1590/S2197-00252013000100007

Rodrigues-Corrêa, K. C. D. S., de Lima, J. C., and Fett-Neto, A. G. (2012). Pine oleoresin: tapping green chemicals, biofuels, food protection, and carbon sequestration from multipurpose trees. Food Energy Secur. 1, 81-93. doi: $10.1002 /$ fes 3.13

Rodrigues-Corrêa, K. C. D. S., de Lima, J. C., and Fett-Neto, A. G. (2013). "Oleoresins from pine: production and industrial uses," in Natural Products, eds K. G. Ramawat and J.-M. Mérillon (Berlin Heidelberg: Springer), 4037-4060.
Rodrigues-Corrêa, K. C. S., and Fett-Neto, A. G. (2012). "Physiological control of pine resin production," in Pine Resin: Biology, Chemistry and Applications, eds K. C. S. Rodrigues-Corrêa and A. G. Fett-Neto (Kerala: Research Signpost), 25-48.

Savage, T. J., Hatch, M. W., and Croteau, R. (1994). Monoterpene synthases of Pinus contorta and related conifers. A new class of terpenoid cyclase. J. Biol. Chem. 269, 4012-4020.

Song, J.-D., Kim, J.-H., Lee, D.-H., Rhew, T. H., Cho, S. H., and Lee, C.-H. (2005). Developmental regulation of the expression of 1-aminocyclopropane1-carboxylic acid (ACC) synthase and ACC oxidase genes in hypocotyls of etiolated mung bean seedlings. Plant Sci. 168, 1149-1155. doi: 10.1016/j.plantsci.2004.11.015

Stubbs, J., Roberts, D. R., and Outcalt, K. W. (1984). Chemical Stimulation of Lightwood in Southern Pines. Asheville: United States Department of Agriculture, General United States Department of Agriculture, Forest Service.

Trapp, S., and Croteau, R. (2001). Defensive resin biosynthesis in conifers. Annu. Rev. Plant Physiol. Plant Mol. Biol. 52, 689-724. doi: 10.1146/annurev.arplant.52.1.689

Tu, L., Zhang, X., Liu, D., Jin, S., Cao, J., Zhu, L., et al. (2007). Suitable internal control genes for qRT-PCR normalization in cotton fiber development and somatic embryogenesis. Chinese Sci. Bull. 52, 3110-3117. doi: 10.1007/s11434007-0461-0

Vandesompele, J., De Preter, K., Pattyn, F., Poppe, B., Van Roy, N., De Paepe, A., et al. (2002). Accurate normalization of real-time quantitative RT-PCR data by geometric averaging of multiple internal control genes. Genome Biol. 3, research0034.1-research0034.11. doi: 10.1186/gb-2002-3-7-research0034

Wang, L., Xie, W., Chen, Y., Tang, W., Yang, J., Ye, R., et al. (2010). A dynamic gene expression atlas covering the entire life cycle of rice. Plant J. 61, 752-766. doi: 10.1111/j.1365-313X.2009.04100.x

Wang, M., Wang, Q., and Zhang, B. (2013). Evaluation and selection of reliable reference genes for gene expression under abiotic stress in cotton (Gossypium hirsutum L.). Gene 530, 44-50. doi: 10.1016/j.gene.2013.07.084

Conflict of Interest Statement: The authors declare that the research was conducted in the absence of any commercial or financial relationships that could be construed as a potential conflict of interest.

Copyright (c) 2016 de Lima, de Costa, Füller, Rodrigues-Corrêa, Kerber, Lima, Fett and Fett-Neto. This is an open-access article distributed under the terms of the Creative Commons Attribution License (CC BY). The use, distribution or reproduction in other forums is permitted, provided the original author(s) or licensor are credited and that the original publication in this journal is cited, in accordance with accepted academic practice. No use, distribution or reproduction is permitted which does not comply with these terms. 